\title{
Holdenby, Northamptonshire; Its Manors, Church and House
}

\section{Albert Hartshorne F.S.A.}

To cite this article: Albert Hartshorne F.S.A. (1908) Holdenby, Northamptonshire; Its Manors, Church and House, Archaeological Journal, 65:1, 89-120, DOI: 10.1080/00665983.1908.10853079

To link to this article: http://dx.doi.org/10.1080/00665983.1908.10853079

里 Published online: 17 Jul 2014.

Submit your article to this journal $₫$

Џ Article views: 2

Q View related articles 


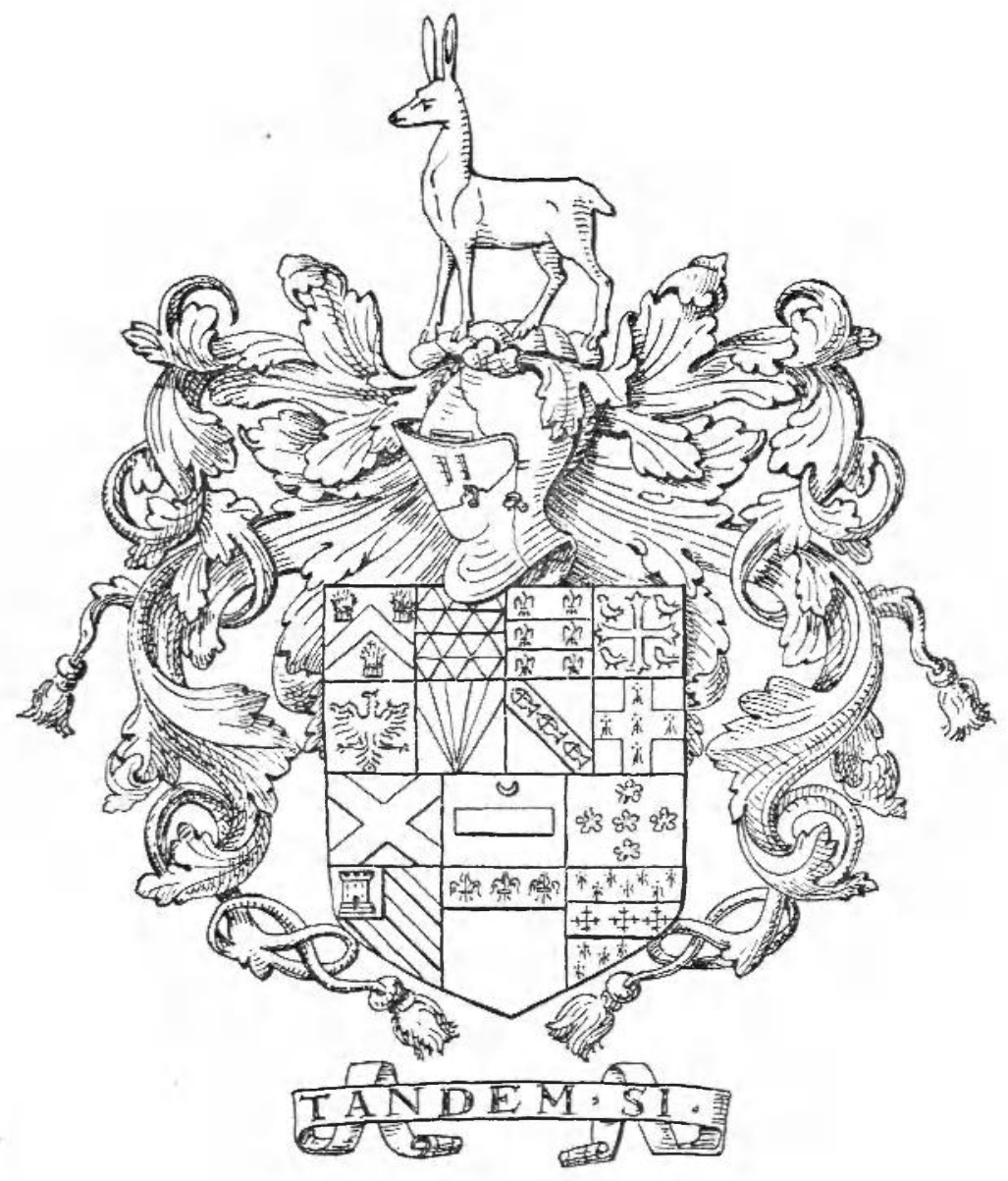

ATCHIEVEMENT OF SIR CHRISTOPHER HATTON.

From Treswell's Bools of Surveys, 1580. 


\section{HOLDENBY, NORTHAMPTONSHIRE; ITS MANORS, CHURCH AND HOUSE. ${ }^{\prime}$}

By ALBERT HARTSHORXE, F.S.A.

Holdenby is, on many accounts, one of the most interesting places in Northamptonshire. It has a long and well-ascertained manorial history: the church, not large, has much dignity, and presents a striking appearance, even in a county singularly favoured architecturally. The account of Holdenby has fallen, naturally, into the scheme of two very considerable county histories of the old stately type such as used to be looked upon, and must, indeed, still be justly regarded as the foundation stones of every great English library.

Concerning Bridges's History of Northamptonshive it may be conveniently stated now that its author was a Northamptonshire man, born at Barton Seagrave in 1666. He became a Bencher of Lincoln's Inn, and Solicitor to the Customs in 1695, holding other lucrative offices. Towards the latter end of his life, namely, in 1719, he began to form his collections and, had he been spared to enable him to complete his labours, it is believed that his History would have rivalled Dugdale's Warwickshire. He died in 1724, having made his first personal survey of every parish in the county, intending to repeat it on a future occasion. His collections came into the hands of his brother, who took steps to have the copious material arranged into a regular and connected history by placing the manuscript in the hands of one Gibbons, a bookseller, who employed Dr. Jebb to carry out the work in numbers. Gibbon's bankruptcy occurred after the first part was issued, and it was not until towards the end of the century that a committee of gentlemen of the county discharged Dr. Jebb's claims, obtained the manuscript, and commissioned the Rev. Peter Whalley, with others, to prepare them for continuation of publication. The work

1 Read at the meeting of the Royal Archaeological Institute, March 4th, 1908. 
was not very well done, and though the History did not appear until 1791, sixty-seven years after Bridges's death, such simple matters, for instance, as the continuation of names of lords of manors, and lists of incumbents, were not even attempted. The last incumbent entered as of Holdenby was Daniel Amiand, who was presented to the living in 1691 and died in 1730. Of this rector we shall hear more later on.

Baker's History is in every respect superior to that of Bridges, and its story is still more inauspicious, and indeed, calamitous. He issued his proposals for a new county history in 1815 , and it must be admitted that, for the time, his manorial and pedigree work are excellent. Those were early days in which to expect correct antiquarian and architectural knowledge, and on both these lines Baker's descriptions leave much to be desired. His History comprises only the southern part of the county. One would, indeed, be inclined to think that a great county history is rather beyond the powers of a single individual, so many and so high are the necessary qualifications, did not such stately folios as those of Ormerod and of Nichols give us pause. In the present case, loss of subscribers, loss of fortune and discouragement, worse than death, caused George Baker to abandon his project in 1841; and he witnessed with a heavy heart the dispersal of his collections.

\section{MANORIAL HISTORY.}

Taking now the manorial history of Holdenby, as set forth by the two authorities, it should be observed that Siward held "Aldenesbi" in the time of the Confessor; at the Great Survey it was held by Ralph, under the Earl of Moreton-the Moreton fee. In the Hydarum of Henry II., there were certified to be three hides in Holdenby of the fee of the Earl of Leicester. On the subsequent division of that earldom, the paramountship of this estate passed in portions to the honours of Winchester and Leicester, under each of which were held two manors.

I. Of the honour of Winchester. 1. The Arden or Holdenby manor.--In 18 Henry III. (1233-4), a fine 
was levied between Eustachia de Pinkeney and Henry de Pinkeney, of the service of one knight's fee and a half in Haudenby, and Sprocton, claimed by Margaret, Countess of Winchester ; and in 54 Henry III. (1269), Peter de Holdenby held half a fee in Holdenby of her and her son Thomas. She had married Thomas de Arden, and it is stated that "when this manor occurs in the inquisitions of their descendants, it is to be understood as expressive only of the intermediate seignory which they retained between the Holdenbys, the mesne lords and the chief lords, or representatives of the honour of Winchester.

The family which bore the local surname was seated here as early as in the beginning of the thirteenth century, and continued in the direct male line until the beginning of the sixteenth century. In 1511, Joyce, widow of John, son of William Holdenby and Margaret Jakes, died seized of the manor of Holdenby and other lands. Elizabeth Holdenby, sister of William, was therefore found to be the next heir, Robert, only child of John and Joyce, and the last of the ancient race, having died without issue in his father's lifetime.

Elizabeth Holdenby married firstly Henry Hatton, third son of Peter Hatton of Quisty Birches, of the ancient Cheshire family, and had issue John Hatton of Holdenby, who married Jane Westby from Kent. Their eldest son, William Hatton of Holdenby, married Alice Saunders and died in 1546, leaving issue, 1, Francis, died under age in 1546; 2, Christopher ; 3, Dorothy, who married John Newport of Honingham, co. Warwick, and was dead in 1591.

Of the honour of Winchester. 2. The Nevill manor.In 13 John (1211) Philip de Haudenby and Julian his wife, who held certain lands here which, after her death, should descend as his inheritance to Robert Trian, her nephew, were summoned for endeavouring to defraud the said Robert by the adoption of a child, and passing it as their son and heir. Philip and Julian were accordingly adjudged to forfeit the fee, and seizin thereof was given to Robert Trian. In 38 Henry III. (1253) Ralph de la Hay, who married Eustachia, sister and heir of Robert Trian, died seized of Brampton and Holdenby 
manors. From him they descended to the Nevills. By inquisition taken on the death of Roger de Quincy, Earl of Winchester, in 54 Henry III. (1269), Philip Nevill and Sibil de Holdenby were certified to hold one knight's fee in Holdenby, and in 9 Edward II. (1315-6) Philip's younger grandson, William, was lord of Holdenby and Whilton. From this time the connection of the Nevill family with Holdenby appears to have come to an end, and their estates here cannot now be identified.

II. Of the honour of Leicester. 1. The Covele manor. In 25 Henry III. (1240-1) Philip de Covele is returned to hold one fee in Haudenby and Ravensthorpe, of the fees of Simon de Montfort. Of Philip's four daughters, Joan and Isabel died without issue. Margery married secondly William de Holdenby, and had a son and a nephew of the same name; the latter married Alice, daughter of Sir John Verdon. The fourth daughter married Roger de Broke. Complicated legal proceedings arose among the numerous descendants of the daughters of Philip de Covele concerning the manors and appurtenances in Holdenby and the adjacent parish of Ravensthorpe up to the middle of the fourteenth century.

Of the honour of Leicester, barony of Keynes. 2. The Welles manor. In the Testa de Nevill, c. 19 Henry III. (1234-5) Hugh de Vallibus held the fourth part of a fee in Holdenby, of the fees of Ralph de Keynes then in wardship of Simon de Montfort. In 24 Edward I. (1295-6) Peter de Welles held four virgates of land in Holdenby of the heir of Robert de Keynes, who held them of the Earl of Leicester. He died in 1307, aged 80, an unusually long life for that period. No further trace of the Welles family occurs until 3 Henry VII. (1488), when, by a rental of the feudatory tenants of the manor of Dodford, it appear's that Peter de Welles held in Holdenby the third part of a knight's fee which John Wells, John Holdenby, and others lately held.

All the four manors of Holdenby are thus, and so far accounted for by the old county historians, and the association with them of the locally-named family in some measure shown. All four merged in the Hatton estate, but at what precise times has not been ascertained.

The slight consideration of the manors has naturally 


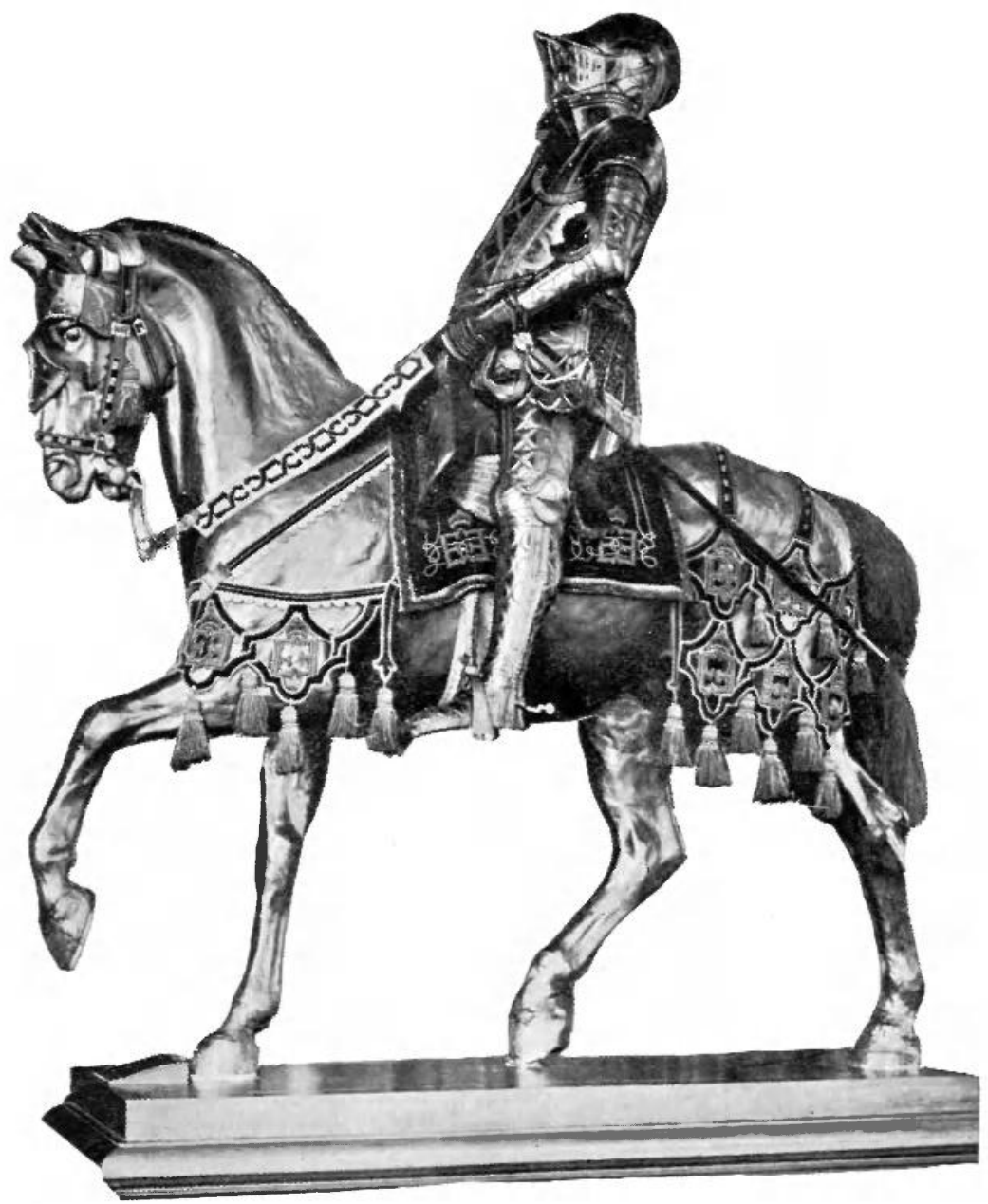

SLIT OF ARMOLR OF SIR CHRISTOPHER HATTON IY HIS NAJESTY'S COLLECTION AT WINDSOR. 


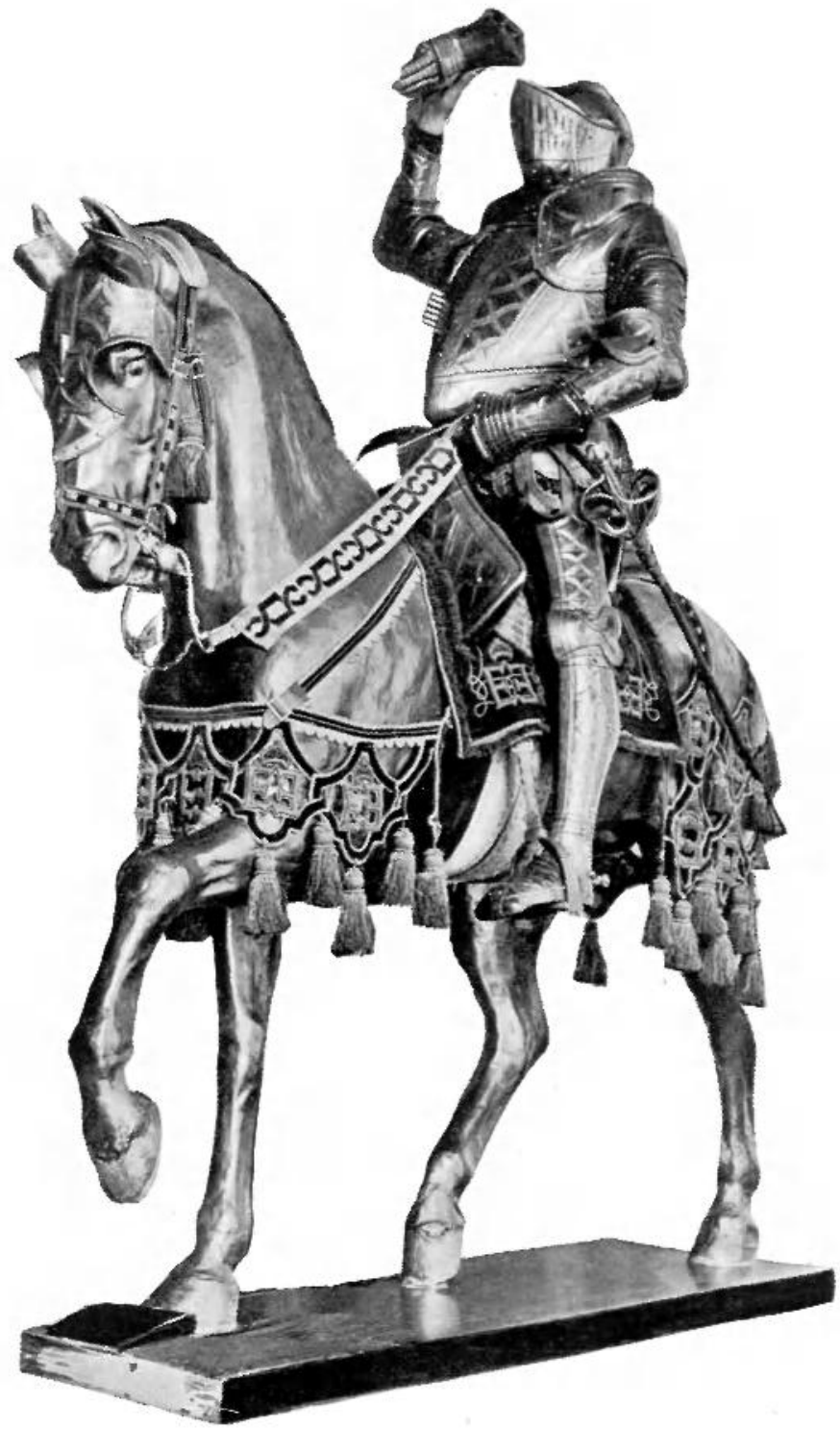

SEIT OF ARMOER OF SIR CHRISTOPHER HATTON IN HIS MAJESIY'S COLLECTION AT WINDSOR. 
brought about references to the ancient possessors and resident lords of Holdenby. It appears that a family bearing the local surname was seated here from the beginning of the thirteenth century, continuing in the direct line for three hundred years. And we have seen that early in the sixteenth century Henry Hatton married Elizabeth, heiress and last of the ancient family of Holdenby.

Due south-west of the church and hard by upon a plateau, of which the low earthen ramparts are still plainly to be seen, stood the old mansion house of the Holdenbys. Here, in 1540, was born the great grandson of Elizabeth Holdenby, Christopher Hatton, a personage too well-known in history to necessitate in this place a lengthened biographical notice. It will suffice to say only a few words; his works at Holdenby will be dealt with later. $\mathrm{He}$ certainly owed much to his handsome person and carriage, and found, as did others, great favour in the eyes of his susceptible monarch. He became one of her gentlemen pensioners, and an order was given to the Master of the Armoury for a complete suit of armour to be made for him ${ }^{1}$ (Plates I and II). He rose rapidly, and if his personal advantages stood him in good stead, it was allowed at the time that his sudden promotion to the Lord Chancellorship, without probation in subordinate office, did not find him lacking either in acuteness of perception or in the rectitude of his judgments. He had, in fact, been a student of the Inner Temple. His place, it was said, as keeper of the Great Seal, "was above his law, but not above his parts, which were very pregnant and comprehensive." Honours and dignities, royal and academic, came thick upon him. $\mathrm{He}$ showed himself bountiful in alms, and a great upholder of learning. He bought Kirby Hall in Northamptonshire in 1575 , then newly erected after the designs of John Thorpe, from the heirs of Sir Humphrey Stafford,

1 This suit is now in the Royal Collection at Windsor. It is from the anvils of Jacob Topf, a German who worked in England. It is here illustrated from photographs kindly lent by Mr. Guv Laking, M.V.O.

2 But this does not seem to have been the common opinion. Ben Jonson makes one of the characters in the masque performed at Althorp, in 1603 before Anne of Denmark, say :

"I do not deny where Graces meet In a man that quality

Is a graceful property

But when dancing is his best, Beshrew me I suspect the rest." 
and built the great house of Holdenby, and formed the artificial gardens, during the next decade. Here he lived in the usual style of costly hospitality of the period; the main object of such great palaces, which then arose, being the reception and entertainment of Queen Elizabeth and her court.

The four mediaeval manors of Holdenby were exchanged with the queen by Sir Christopher Hatton, April 19th, 1568, under the general description of "Holdenby," for the site of the abbey and demesne lands of Sulby in the same county. On January 10th, 1570 , the queen reconveyed to him the manor of Holdenby in fee. His end, said to have been accelerated by the pitiless conduct of the queen, came in 1591, at the age of fifty-one. Sir Christopher Hatton died unmarried, having settled his estates by deed on his nephew Sir William Newport, obliging him to take the name of Hatton, with remainder to his godson and heir male Sir Christopher Hatton of Long Stanton, Cambridgeshire. This Sir Christopher's descendant, Anne, only daughter of Christopher, Viscount Hatton, married (as his second wife) in 1685, Daniel Finch, seventh Earl of Winchilsea, and second Earl of Nottingham.

Sir William (Newport) Hatton died in 1596, when his Benefield and Newport estates descended to his two daughters and co-heirs; Holdenby, Kirby, and the other Hatton estates passing, by virtue of the Lord Chancellor's remainder, to Sir Christopher Hatton, of Kirby.

In 1607, Sir Christopher Hatton, by the power of an act of parliament, conveyed "the greate mansion-house of Holdenby," the manor, etc., to the King, with remainder to Charles, Duke of York, in tail male, etc. The King covenanted to pay for the mansion and other buildings, and the timber; to ensure to Sir Christopher Hatton and his heirs, certain manorial rights, to the yearly value of $£ 1,65213 s .11 d$, and to grant the custody of the great mansion house of Holdenby, and the edifice called the Dairy House, as a lodging for her during her life, to Lady Elizabeth (Newport) Hatton, daughter of Thomas, first Earl of Exeter, and then the second wife of Lord Chief Justice Sir Edward Coke. Perhaps the strained relatiors between Sir Edward and his wife made it desirable that 
she should have a refuge elsewhere than at Tittleshall where the recollections of her predecessor, the gentle and beloved Bridget Paston were not likely to have been forgotten. ${ }^{1}$

By the succession to the throne of the Duke of York in 1625 , Holdenby passed to him under the entail. Proceeding from the fateful raising of the royal standard at Nottingham, some of the results of the great national drama will only be lightly touched upon in their places, as far as Holdenby is concerned. It need only be added here that, after the Restoration, these Crown lands came into the hands of James, Duke of York, who sold them to Louis Duras, created Baron Duras of Holdenby, in 1672. He married Mary, daughter and co-heir of George Earl of Feversham, to which peerage he was in remainder, and succeeded in 1677. Dying without issue in 1709 his titles became extinct.

From the representatives of the Earl of Feversham, Holdenby was bought by the illustrious John Churchill, Duke of Marlborough. By a special act of parliament all his honours were entailed on his eldest daughter and her heir male with remainder in like manner to his other daughters. The duke made a corresponding disposition of his estates, so that, on the death in 1733 , of the eldest daughter, wife of Francis, Earl of Godolphin, without such issue male, Charles Spencer, fifth Earl of Sunderland, by virtue of the parliamentary settlement became second Duke of Marlborough, and owner of Holdenby. His son George, third duke, sold the manor and lordship in 1802 to the trustees of Henry Welbore Agar Ellis, second Viscount Clifden in the peerage of Ireland, whose great grand-daughter, the present possessor, married Luke, third Lord Annaly, has issue, and lives at Holdenby House.

\section{THE CHURCH.}

We pass now to Holdenby church. It will have been anticipated that with so long a succession of lords of manors, some of them resident, many monumental

1 There is a beautiful full-length portrait of Dame Bridget, by Janssen, at
Holkham, illustrated in Mrs. A. M. W Stirling's Coke of Norfolk, i, 10 (1907). 
memorials would have survived. And such is indeed happily the case, though we have record and fragmentary evidence of other memorials which have perished. Apart from the information set forth in the two printed county histories, we have, preserved in the Bodleian, the Church Notes made by Belcher, who died in 1609, and thirtynine folio volumes of Bridges's collections, on which his history is founded. On examining Belcher's notes of the memorials proper which he noticed, only two inscriptions, namely those to Alice Saunders, wife of William Hatton, and to Dorothy, daughter of Laurence Saunders, now remain. He also gives the trickings of the seven coats on the font; the impaled coat on the memorial of William Hatton and Alice Saunders, parents of Sir Christopher ; and those on the two banner's over the tomb of the first wife of Sir William (Newport) Hatton, Elizabeth, daughter and heiress of Sir Francis Gawdy, Chief Justice of the King's Bench. These ensigns show Hatton of twelve quarters impaling Vert a tortoise Arg. Gawdy; and Gawdy impaling Gu. three conies Arg. Coningsby the bearings of Elizabeth's father and mother. Belcher further gives the impaled arms of William Holdenby and Margaret Jakes, which as he notes, appear "on William Holdenby's Mon"" (Plate III). Also a shield showing twelve roundels, a canton Erm.; two others without the canton and an atchievement showing Hatton differenced by a crescent, quartering Holdenby, Carville, and Washingley, and impaling . . . ? a Saltire Or, four annulets Arg. In addition Belcher shows a quarterly coat, namely 1 and 4 Hatton ; 2 and 3 Hallom, and Az. a mullet Sa. quarterly. The whole of the above-mentioned heraldic records, excepting those of William and Margaret Holdenby have quite vanished, they are here illustrated (Plate IV).

The church is of the usual Northamptonshire plan, comprising nave, aisles, chancel and western tower. Although the building cannot compete with any type in the long and matchless procession of churches along the valley of the Nene, it takes a good position among churches of like character in the southern part of the county. It has not, for instance, the known historical interest of the church in the adjoining parish of Harleston; it cannot rival the Transitional work of 


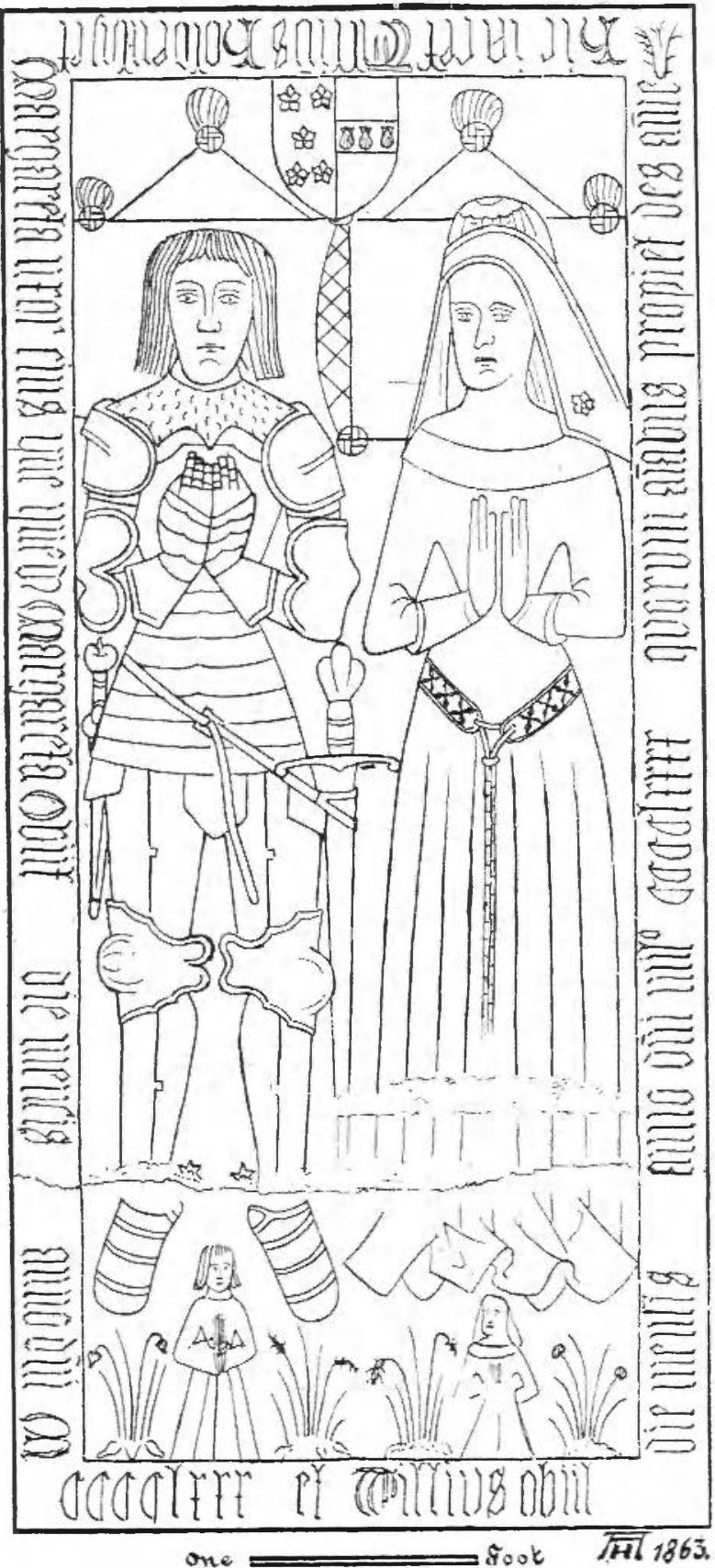

INCISED SLAB OF WILLIAM AND MARGARET HOLDENBY, 
PLATE IY.

To face page 96.
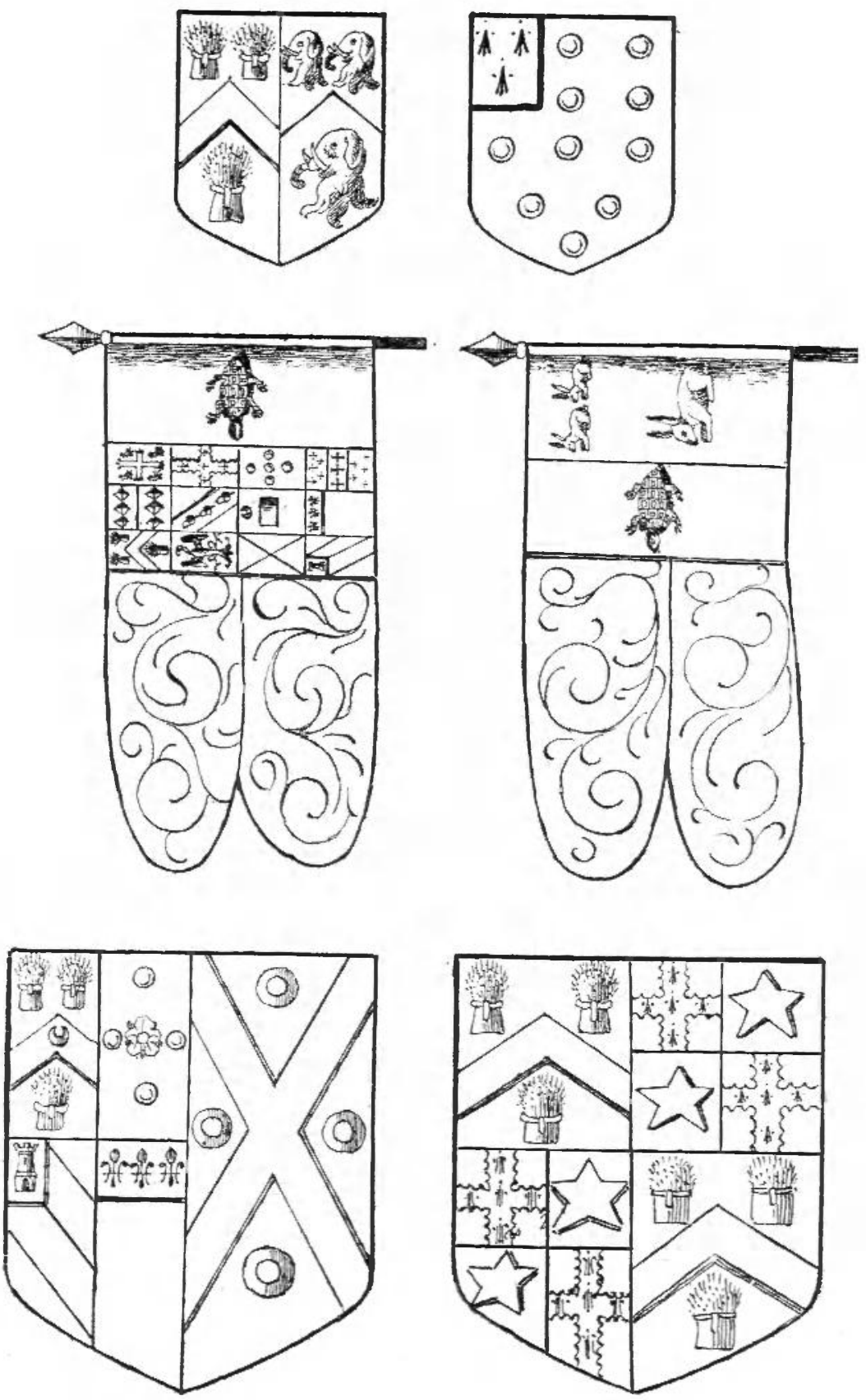

ARMS FROY BELCHER'S MES. 
Spratton, nor can it present original late Perpendicular wood work, dating between 1445 and $14 \overline{5} 7$, and noble Renaissance tombs, such as delight the eye in the neighbouring church of Brington. But the interior of Holdenby church has an impressive dignity which is uncommon, and striking in a building of its moderate size. And although the church suffered in 1867 from a "restoration" somewhat drastic, even that pitiless process, which included the senseless denudation of the ancient walls, could not destroy the innate merit of its proportions. 'The date of the nave with its well ordered arcades being about 1330-40, one is not surprised to find the evidences of small circular clerestory windows on the north side, just as they appear at Lichborough, and at Byfield, respectively ten and fifteen miles off. The north aisle, into which steps descend from the churchyard, is unusually narrow. It appears to have been rebuilt after the middle of the fifteenth century, and raised, when the use of the clerestory lights was abrogated. The south aisle, unusually wide and co-eval with the nave, has had its windows filled with new tracery, to which, perhaps, no exception can be taken. In the south wall of the south aisle is a low arched recess, which contained in Bridges's time " the wooden statue of a man in a buttoned gown, with an iron sword and head-piece laid by him." "This was evidently a monument of the early part of the reign of Edward III., and probably represented Robert Holdenby who married Joan, daughter of Richard Zouche, and may be taken to have been the builder of the greater part of the church. According to local tradition, the effigy, sword, and head-piece were taken away many years ago by a gentleman of the neighbourhood, who came in his carriage for the purpose. In the same aisle is a monumental slab sculptured with a floriated cross, and narrowing to the foot. 'This is of the latter end of the thirteenth century and is the earliest memorial in the church. In the same aisle is the old altar slab, of dark marble. It is marked with the five crosses and has been utilised for the inscription, and four shields of Elizabeth Hatton, heiress of the Holdenbys. Also, the incised slab of William and Margaret Holdenby, one of the four examples in the county. A new porch 
has been set up on the lines of the old one, which was existing in Bridges's time. Access to the church was formerly gained through a south door of Renaissance design, probably brought from the House, as it was in Ketton stone; this was "restored" away. The tower, perhaps contemporary with the nave in its lower portion, has its upper or belfry stage of about a century later embattled, and of something the same general character as that of the adjoining parish of Ravensthorpe. The chancel, designed by Sir Henry Dryden on that of Moreton Pinkeney, was built in 1845 from his own working drawings, at the cost of the Rev. John Lloyd Crawley.

This gentleman, who was also rector of Heyford, seven miles off, where he lived, became rector in 1809; there was no rectory or glebe at Holdenby. He instituted a suit in Chancery by which he recovered the great and small tithes of the whole parish, raising the value of the living from $£ 80$ to nearly $£ 700$ a year. In consequence of the peculiar feeling thus engendered in the place, none of the farmers would take in his horse on Sunday. Mr. Crawley was therefore constrained to set up a stable in the churchyard, his only freehold. This was taken down by the Rev. C. H. Hartshorne, under a faculty, in 1857 , and the materials used in outbuildings to the new rectory which he had built in 1854 . In further consequence of the ill feeling against Mr. Crawley, he had to receive some of his tithe in kind, and at one time the wool was stored in the old chancel.

With regard to the furniture of the church, there are in the chancel a series of eight stalls of excellent design, four on either side, with the usual misericord seats. Bridges speaks of six on each side. These have been thought to appertain to a chantry founded by Robert Holdenby in his mansion house in 1391. But they have an older appearance. They were rearranged in the present number of seats, with new frontlets in 1845 . Some portions which could not be made use of were sheltered at Canons Ashby until 1899, when they were given by Miss Dryden to the Northampton Museum.

By the "restoration" of 1867 the ancient octagonal font, standing against the western face of the western- 

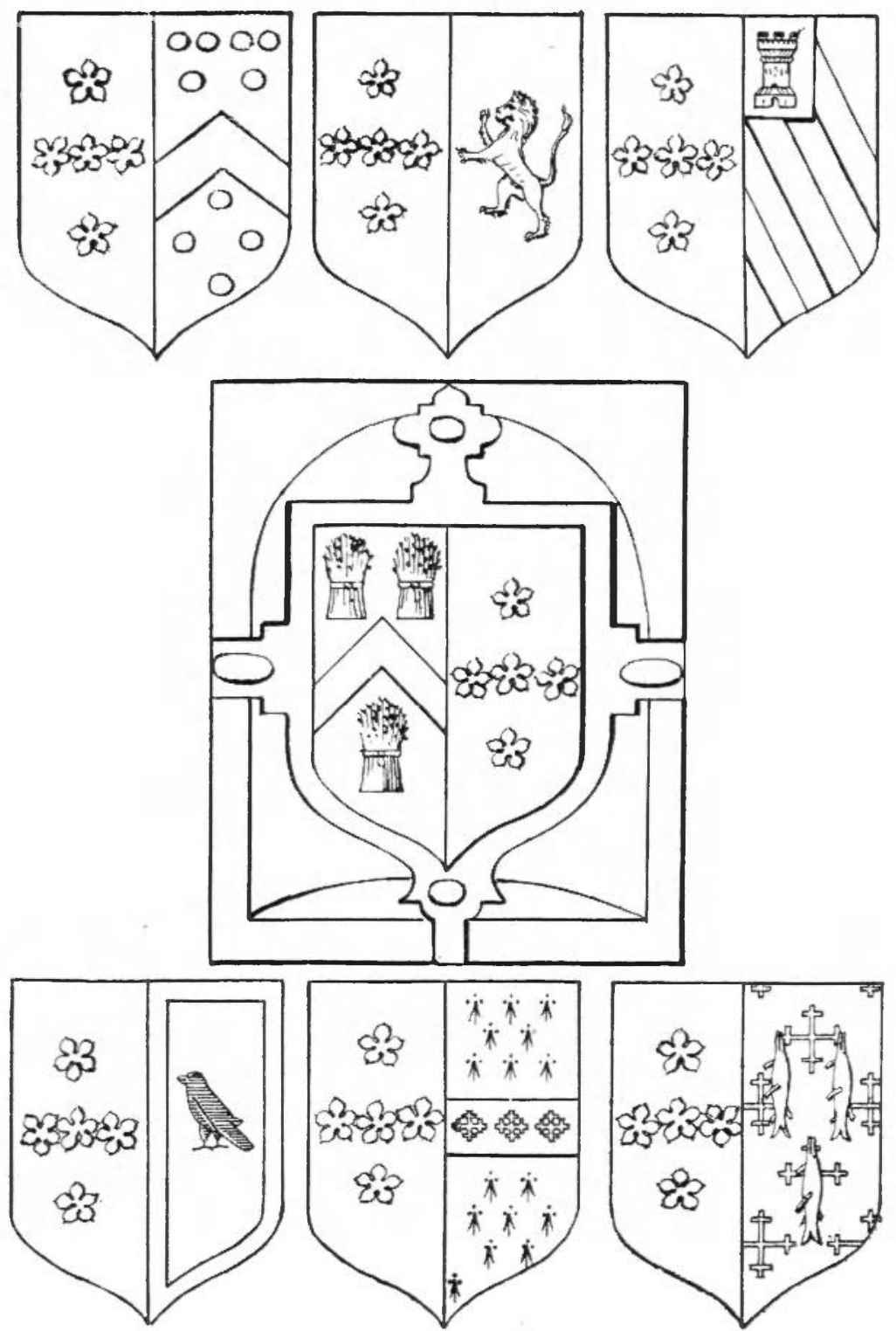

ARMS ON THE FONT AT HOLDENBY, DESTROYED IN 1867. 
most pier of the south arcade, was most wickedly destroyed. In this font, no doubt, Sir Christopher Hatton had been christened. It was painted with seven armorial bearings, within Renaissance frames, showing the marriages of the six predecessors of Elizabeth Holdenby, namely, Robert Holdenby and Joan Zouche; William Holdenby and Alice Verdon; Robert Holdenby and Maud de la Carville; John Holdenby and Margaret Raven ; John Holdenby and Joan Mortimer and William Holdenby and Alice Lucy-and her own alliance with Henry Hatton. In its place was introduced a panelled and cusped stone font of no historical interest whatever. This heraldry was recorded by Belcher before 1609, and was drawn to scale by the writer in 1863 . The coats are here illustrated (Plate V).

Dividing the chancel from the nave is an oak screen of Renaissance design and date. In 1691 Daniel Amiand was instituted as rector. He died in 1730 . Bridges, who began his survey of the county in 1719 , records, as the manorial history shows, that when he visited Holdenby it belonged to the Duke of Marlborough, and that the church was "divided from the chancel by a carved screen of very good workmanship." The first duke died in 1722. The second duke who possessed the place, did not succeed his aunt until 1733 . Baker, whose information is doubtless obtained from Bridges's collections, adds that the screen was " the gift of Mr. Amiand." it must, therefore, have been set up between the date of Mr. Amiand's institution in 1691, and the death of the first Duke of: Marlborough in 1722 .

The experience of having measured and planned on the spot the exterior elevations of Kirby Hall, more than thirty years ago, gives one some information concerning the rapidity of the progress of decay in a dismantled, abandoned, or "slighted" building. Walls become disheartened and soon lose cohesion, tall chimneys and gables deprived of the protection of the roofs tremble in the wind, ceilings plunge into the abyss, and ivy seizes the fabric in a deadly grasp. We shall see presently under what circumstances Holdenby House was sacrificed as a whole: for the moment we are concerned only with one of its parts, namely, the screen at the 
upper or dais end of the great hall, dividing the way to the "stately ascent" to the great chamber from the chapel. In the plan of Holdenby House by its architect, John Thorpe, happily preserved in the well-known collection in the Soane Museum, ' Fig. 1, we have minutely set down the very screen, just as it still appears in the church,

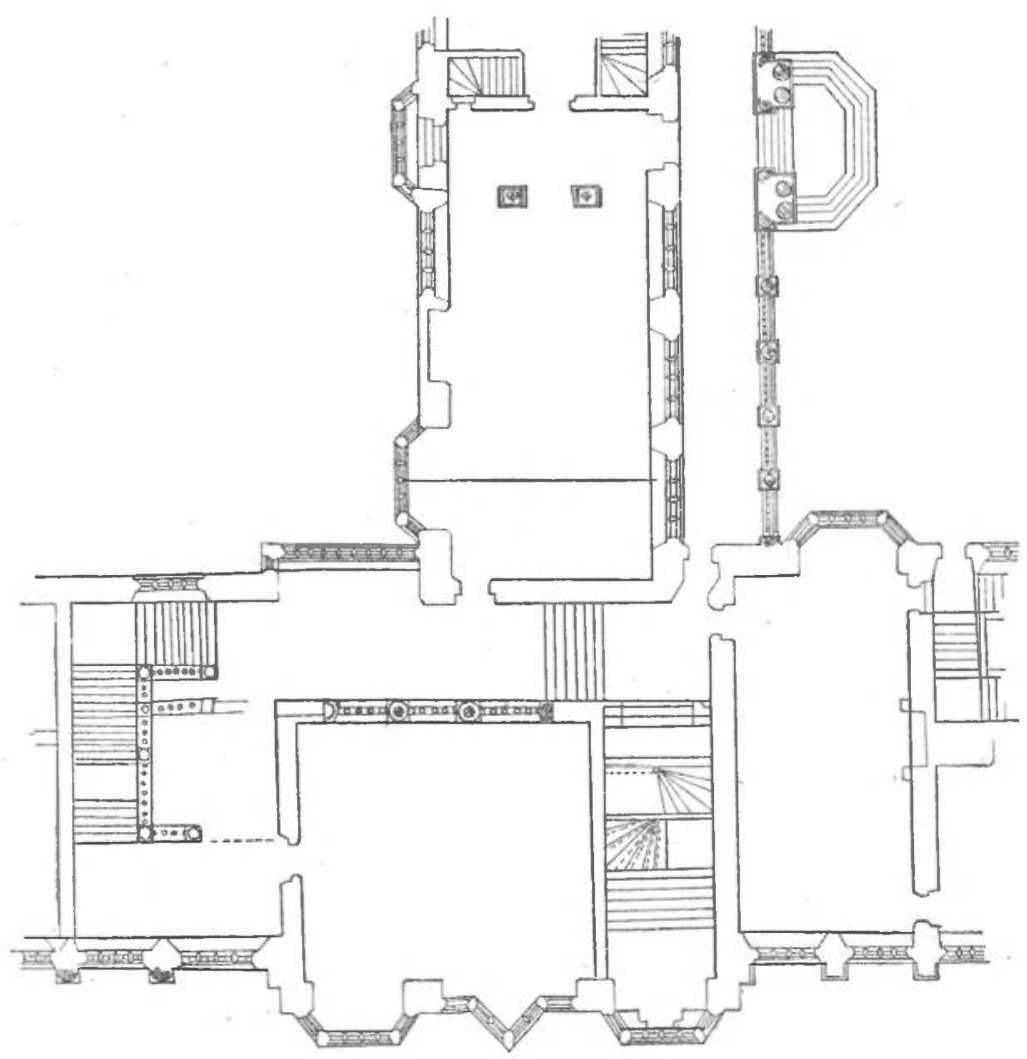

FIG. 1.-PART OF JOHY THOBPE'S ORIGIYAL PLAN OF HOLDENBE HOCSE.

with its four main columns, its narrower central portion and its subsidiary shafts and half shafts, the only difference being that the narrower central portion now offers a clear gangway, as it evidently did in the House. On the beam of the screen stand the oak figures, 2 feet $3 \frac{1}{4}$ inches

' $A$ tracing of the original plan was exhibited to the meeting by Mr. J. A. Gotch. 


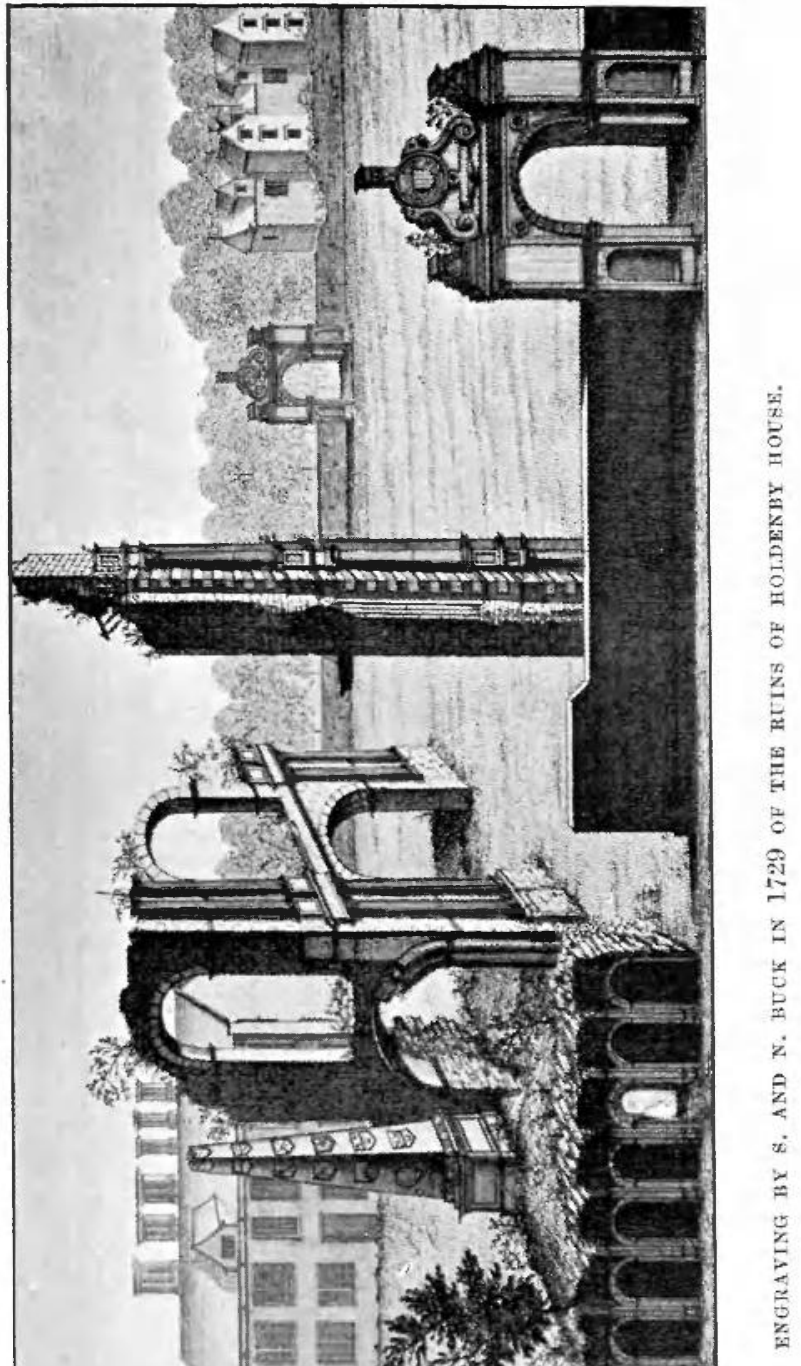


ligh, of two Roman soldiers, bearing shields charged with the head of Medusa. One of the figures is here illustrated, Fig. 2. In 1709 Stukely made a sketch of the ruins of Holdenby House, Fig. 3, in which appears the upper part of one of the two pyramids marked on Thorpe's plan at the lower end of the great hall, and a portion of another. In execution, as is recorded by Norden, there were three such pyramids. This sketch shows rudely much confusion and ruin. Nearly half a century before, Evelyn in his Diary states that the House, seen from Althorp, "showed like a Roman ruin, a stately, solemn, and pleasing view." In Grose's Antiquities there is an engraving dated 1787 , showing the southern archway with the wall forming the base court, and the remaining portion of the house in the distance.

The rapid decay of a forsaken house has been alluded to. The disintegration and swift dissolution of one deliberately thrown down, and its materials sold was much quicker. Mr. Justinian Isham of lamport, six miles off, who succeeded as fifth Baronet in 1730 , visited Holdenby on September 2nd, 1717. He records in his Journal that "the remains show its former magnificence." "Near a hog-stye are two pyramidal pillars on which are several coats of arms," etc.

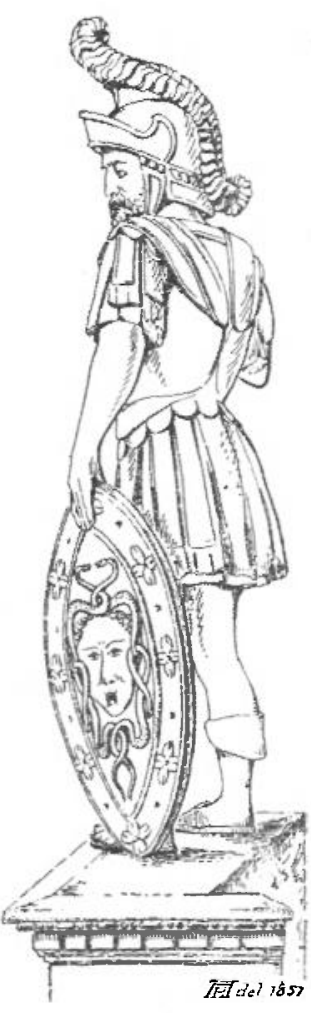
"In the church an ancient font with the arms of Holdenby impaling others," etc. In $1729 \mathrm{~S}$. and N. Buck made their drawing and engraving of Holdenby House, which is here reproduced (Plate VI). This exhibits the artist's usual inaccuracies of perspective. No woodwork then, of course, remained. One of the pyramids is shown. but in nothing like its right place on the plan. 
It may be gathered that the screen must have been transmitted from the house to the church very shortly after the appointment of Mr. Amiand to the living. It was clearly not an object for which there would have been any competition, or any continued domestic use found, considering the utilitarian purposes to which the House was condemned after the Civil Wars. And it so happened that the screen in its integrity almost fitted the chancel arch. But it was necessary to cut away
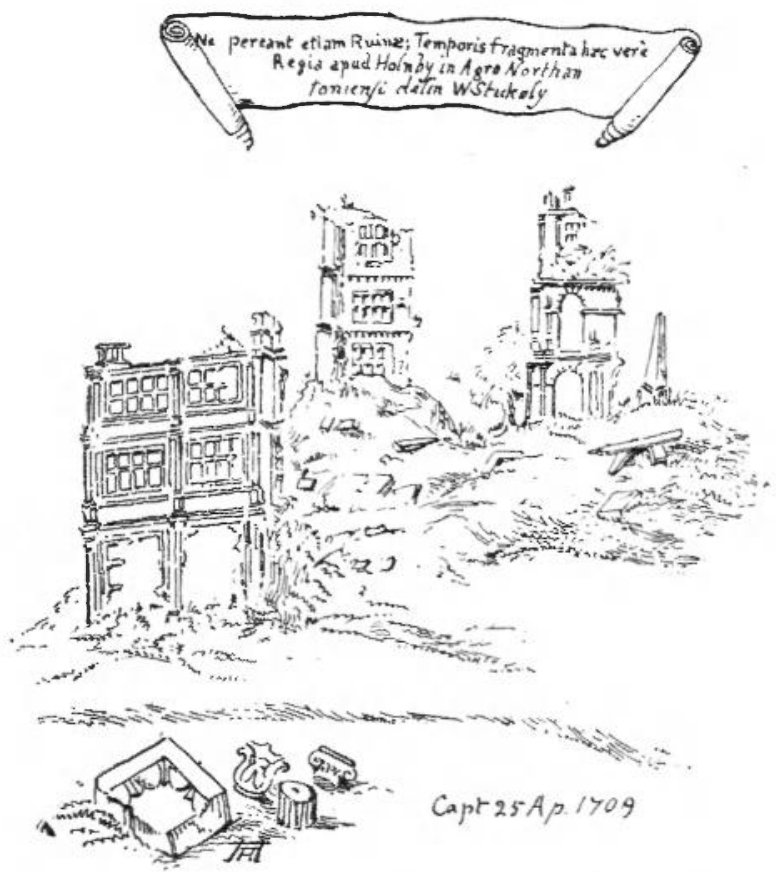

FIG. 3.-STCEELEY'S SEETCH OF THE RTINS OF HOLDENBY IN 1709 .

some of its cornice and to hack away almost half of the northernmost column; some of the hood moulding of the respond of the nave arcade on the north side being chopped off, with the reckless disregard for Gothic antiquity which characterised that dark age. The lower members of the outer ring of the chancel arch on the south side were also removed. The screen is here shown as it appeared up to 1867 (Plate VII, 1). There was another purpose in view. The opportunity was taken to scoop out 


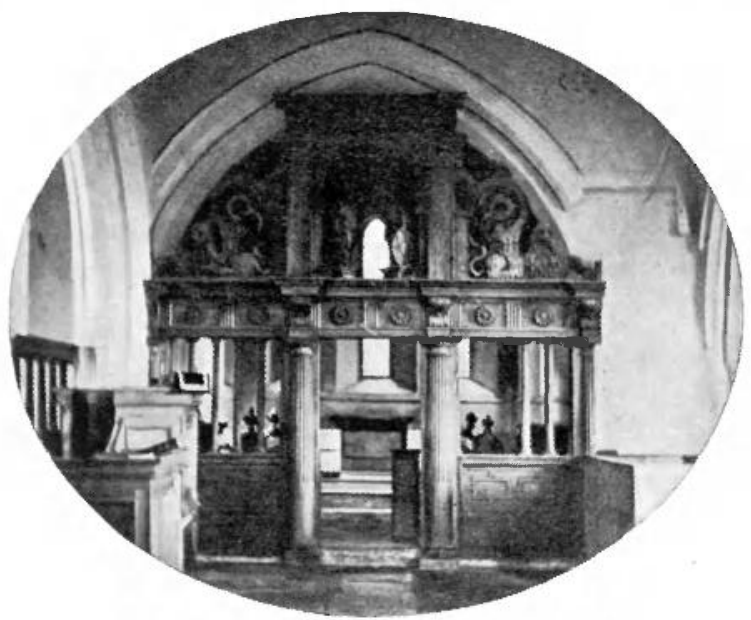

1. BCREEN, NOW IN HOLDENBY CHLRCH.

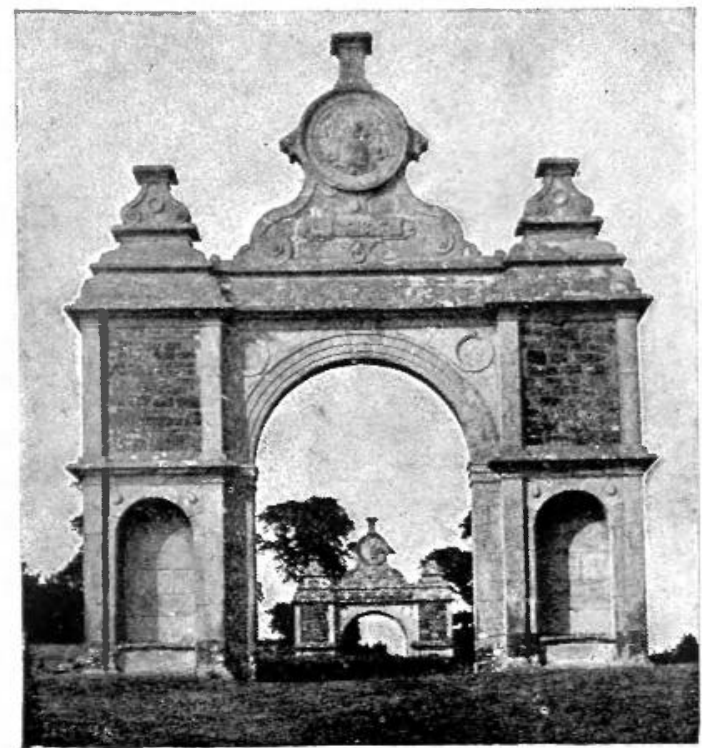

2. HOLDENBY ARCIIES. 
the chancel wall, facing the nave, on the south side, for the purpose of fitting in a pulpit and its attributes in the way that was deemed seemly at the time. This arrangement, which was of a common character, was subsequently modified, the pulpit lowered and brought forward and a pew formed later in the corner. In 1863 the pulpit, the reading desk, and clerk's seat were abolished, and a new oak pulpit and reading desk given by the Rev. C. H. Hartshorne.

It is remembered that the circular-headed opening in the screen formerly contained the Royal Arms, painted on canvas. As to its subsequent fate, when the church was " restored," the upper portion of the screen was most foolishly and aimlessly taken down, and placed on the floor at the east end of the south aisle, where it remains, a great eyesore, and serving no purpose whatever. At the same time the arched opening was fashioned into an entrance to the tower, formed into a vestry. Both these portions should of course be returned at once to their original places, and the screen restored in the best sense to its pristine state, inasmuch as its origin and history is thus established with absolute certainty. In 1863 the present writer made a large scale drawing of it. ${ }^{1}$ It is not an ecclesiastical postReformation screen made for the place. Even in Elizabethan days prominent figures of pagan soldiers would hardly have been accepted as fitting attributes for a chancel screen, whatever latitude may have been allowed in domestic fittings. Nor is it a post-Restoration work, such as the screen at Monnington in Herefordshire, and it illustrates no transient ecclesiological fervour of Georgian times. It is merely an item rescued by the good impulses of the rector, on account of its associations; a remnant of history to be accepted with its "classic" incongruities, " a brand snatched from the burning," and thus becomes more historic than ever. Moreover, the Holdenby screen is a highly interesting example of the acceptance of a chancel screen, separating the clergy from the laity, at so dismal an ecclesiastical time as the early years of the eighteenth century, and, as such, has far more value than any suppositious Elizabethan church origin.

1 This was exhibited to the meeting by Mr. J. A. Gotch. 
Further, the true facts regarding the Holdenby screen are of common knowledge, having been pointed out both in print and in manuscript over and over again.

These things being so, it is somewhat startling to find the following statement, in a book entitled English Church Furniture, which made its appearance last year. "Holdenby church contains a chancel screen of great interest and fine classical design. It dates from about 1580, when the first great Renaissance architect, John Thorpe, was building the magnificent pile of Holdenby House. A fanciful notion has obtained some currency that this screen was not designed for the church, but was moved here when so much of the great house was pulled down in the seventeenth century. 'The plans, however, of the house are extant, and there was no such screen, or any space for it, in any part of the building. The late $\mathrm{Mr}$. Mickleth waite, who paid two special visits to inspect the screen, was able to point out several features that established its construction for a church and not for any house-chapel" (page 128).

In the same volume it is stated at page 285 , perhaps correctly, that several pews of Elizabethan date have been cleared away by restorers, "notably a fine pew of classical design, coeval with the screen, c. 1585, at Holdenby church." This pew, which the compilers of the book can never have seen, but which the present writer had sketched, and knew well, having sat in it scores of times, consisted of a few well moulded panels of different sizes, irregularly made up with an oak and deal framework, and capped by a balustrading formed of small shafts similar to those in the screen, sawn in two halfway up the fluting and set upon clumsy square blocks. The whole was surmounted by a ricketty made up cornice. This was simply a pew formed from portions of woodwork from the House, for the use of the tenant occupying the remaining part of it. It did not even offer an example of one of those offensive and arrogant prerogatives, a "Faculty Pew," now happily never granted, and was undoubtedly roughly put together at the same time that the screen was introduced, being then tinted to match it. It was removed in 1867 , and some of the panel work remains in the belfry of the tower. In the 
march of history this vanished object has dilated into "a remarkable Elizabethan pew"; and it has now so far advanced in dignity as to be even spoken of by persons of lively imagination as "The Royal Pew!" The venerable Dr. Routh of Magdalen laid great stress upon the importance of verifying references; of still higher consequence would seem to be the just estimation and recording of facts. It is hardly necessary to point out the extreme inconvenience of misstatements in a book deliberately compiled, and purporting to be authoritative -one of The Antiquarys Books. Such romances cannot be recalled, and are continuously rising up against the investigators of truth.

(In the walls of the church are six painted tablets of texts in black letter, measuring 9 feet 6 inches by 5 feet, and 8 feet by 6 feet, taken from the "Bishop's Bible" of 1568 , within elaborate Renaissance borders. These were recovered from beneath several coats of whitewash in 1862 and repainted by the present writer. At the same time Mrs. Hartshorne, the rector's wife, painted the Creed, the Lord's Prayer, and the Commandments, in oil colour on zinc, copying the original borders. The nine tablets form an uncommon display, and help to cover the rude nakedness of the pointed rubble walls which the "restoration" of 1868 effected. The earliest Registers are dated in 1754 .

THE HOUSE.

To turn now to Holdenby House. We have seen in the manorial history something of its origin and descent. It would not be within the compass of a limited essay to do more than speak generally of this great building which so soon passed away. In rarious sources, public and otherwise, a great amount of historical information has accumulated concerning Holdenby House, chiefly on account of its having been for half a century in royal hands, often visited by James I. and his Queen, by Charles I. and Henrietta Maria, and used for a time as the prison house of Charles I. This material, in the shape of surveys, remembrances, warrants, journals of 
parliament, inventories, and the like, has been well dealt with at some length by Baker, and in a different and more interesting manner by the authoress of Memorials of Holdenby, who has included reprints of Civil War tracts relating to the place; extracts from the Calendars of State Papers, and the king's "Penitential Meditations and Vows in his Solitude at Holmbey," taken from the Eikon Basilike, ${ }^{1}$ the volume which made its appearance a few hours too late to save him, as many thought it might have done.

More strictly germane to the present purpose are the documents concerning the House in the time of Sir Christopher Hatton. The records first in question are the very interesting set of surveys, maps and descriptions of the estates of the Lord Chancellor, drawn up in 1580, in the possession of the Earl of Winchilsea : of these records Baker had no knowledge. The book of Surveys, etc., which contains later documents of the same character, is preceded by a drawing of Sir Christopher Hatton's arms (Frontispiece), a coat of fourteen quarters, as they appear, now much defaced, upon the arches at Holdenby (Plate VII, 2). Nos. 11, 12 and 14 are respectively the coats of the heiresses, Elizabeth, daughter of William Holdenby, and wife of Henry Hatton; Maud, daughter of William de la Carville, and wife of Robert Holdenby, and Joan, daughter of John Mortimer of Grendon, and wife of John Holdenby. These coats were brought into the Hatton atchievement by Elizabeth Holdenby.

The map, or plan, Fig. 4, which appertains to the Survey of Holdenby, was allowed by Lord Winchilsea to be photographed for Mr. J. A. Gotch, ${ }^{2}$ who has, in his usual felicitous manner, made use of it in his Early Renaissance Architecture in England, in showing the development of the house plan in Elizabethan times and particularly as regards the general and systematic scheme upon which such palaces were set out. A better example than Holdenby House there could not be. The technical name of such a scheme was "the lay-out," and here in the original plan we have the whole thing

1 Memorials of Holdenby, by Emily Sophis Hartshorne, 1868, 8vo. (100 copies only).
${ }^{2}$ Mr. Gotch exhibited the photograph to the meeting. 
before us, drawn by Ralph Treswell in 1584. We will now use Mr. Gotch's own words :

"The accompanying plan of the lay-out of Holdenby gires a good idea of the surroundings of the larger Elizabethan houses. The road between two villages ran along the north side of the park, $A$, and from this road branched another one which led up to the house. While it traversed the park it was allowed to wind according to the undulations

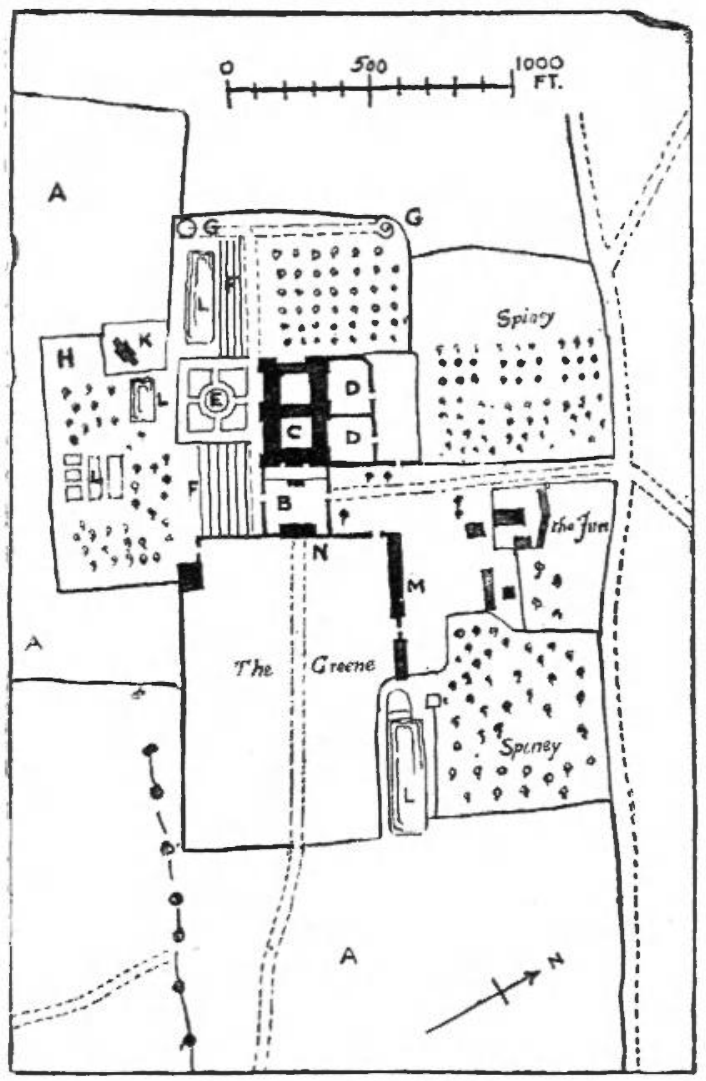

FIG. 4.-THE LAY OUT.

of the ground, but when it came to within a quarter of a mile of the lodge it was made perfectly straight, and so ran through the midst of 'the green '--' a large, long, straight, fair way,' as Lord Burghley called it. It led directly to the porter's lodge, N, which was a building separate from the house, and self-contained, and it passed the long range of stabling on the right, M. The porter's lodge opened into the first court, the 'base court,' B, as it was called, walled round, and entered on its two sides by large gateways. ${ }^{1}$ At the further end of the

1 Still existing and dated 1583 . 
base court stood the house, C, raised a few steps above the general level, where Lord Burghley 'found a great magnificence in the front or front pieces of the house, and so every part answerable to other, to allure liking.' The house was built round two great courts, the first 128 feet by 104 feet, comparable in point of size to those at Hampton Court, and a good deal more intricate in detail. To the north of the house itself were two walled gardens, of nearly an acre each, D, and beyond these were spinneys or small woods, and the little village with its inn. The ground on the south side of the house sloped pretty steeply away, and was laid out in a series of terraces, F. At the top of these, and flanking the whole length of the base court, the house, and the orchard beyond, ran a broad straight path. In the midst of the terraces a great platform, E, was run out at the level of this long path, containing a rosery laid out with paths in a simple geometrical pattern. At the foot of the terraces lay fishponds, L, amid orchard trees, and, in a small enclosure of its own, the church, K. Close to the church was the site of the old manor house, $\mathrm{H}$, the home of Sir Christopher Hatton's fathers, which he found far too insignificant a dwelling for the Lord Charcellor." G indicates the pleasant mounts.

From the testimony of Norden, Camden, Lord Burghley and other contemporaries of Sir Christopher Hatton, there can be no doubt that the house was accurately described as "a fair pattern of stately and magnificent building, making a fair glorious show. On a most craggye and unprofitable grounde" terraces were thrown up, rock excavated, wide shining stews and tangs formed, and with much damming and blasting the palace presently arose, dominating the wide pleasant valley. Less irregular than Burghley, less extravagant in its Tedescan details than Wollaton, less rambling than Kirby, or Audley End, and less refined than Longleat, Holdenby surpassed them all in the beauty of its material, a fine oolite known as Ketton stone, in the dignity of its position, and the regularity of its "lay-out." It was certainly, as was said by Sir Thomas Heneage writing to Sir Christopher Hatton from Holdenby, July 5th, 1583, "the best house that hath been built in this age"; he added eight days later, "I will say, as I think, that, for a gentleman's dwelling of most honour and estimation, it is the best and most considerate built house that yet mine eyes have ever seen"; and, as Norden affirmed, "so beautiful that it may well delight a prince." The House was surrounded by a park of five hundred acres, stocked with red and fallow deer, and wild cattle; there

\footnotetext{
1 Early Rena issance Architecture in England, 75.
} 
was "a large warren of conyes" hard by, and "aboute the house greate store of hares," sounding rather detrimental to the flower gardens.

When Anne of Denmark came from Scotland, June 20th, 1603, she rested for the night at Holdenby, June 24th, and "took a Survey of the House," going on the next day to Sir Robert Spencer at Althorp, where a Masque by Ben Jonson was performed. In a speech by "Nobody," introducing a morris of Clowns, Sir Christopher Hatton, who had been dead for thirteen years, is thus referred to:

They come to see and to be seen, And though they dance before the Queen, There's none of these doth hope to come by Wealth to build another Holmby ; All these dancing days are done, Men must now have more than one Grace to build their fortunes on.

No one would have dared to say as much in the late queen's time !

James I. came to Holdenby in 1608, when Bishop Andrewes preached before him on August 5th, the anniversary of the Gowry Conspiracy, from the significant text 1 Sam. xxvi, 8, 9. He was here also two years later, with the queen, the bishop again preaching on the same happy deliverance, from the text 1 Chron. xvii, 22. The king stayed at Holdenby again in 1614, in 1616 and in 1618. In the prospect of the risit of 1608, and characteristic of the wants of the court at that time, great additions were made to the brewing vessels and utensils, so the spring beer would have been plentiful and in good order.

It may be recalled that in July, 1626, Charles I. expelled all his queen's French attendants, the "Monsers" as they were styled, to the number of four hundred, on account of their " unreverent" behaviour, and in spite of the anger and tears of the queen, then a petulant beauty of eighteen. This gives an idea of the vastness of royal establishments, and the capacity of the houses, and their dependencies, which could receive them. At the end of the year fresh arrangements were made. Henrietta Maria was allowed a bishop, ten priests and a confessor ; certain French personal attendants and serving 
women, and "all the officers of the mouth and of the goblet are to be French." The concession was timely and kind. The king was passionately attached to his wife, and we know from his own words in the last and touching farewell with the innocent "sweet hart," the Princess Elizabeth, at Whitehall, that his thoughts "never strayed from her for a moment."

The queen was at Holdenby in 1627, no doubt attended by all her French retainers. The king was here in 1634, and in 1636, with the queen, who stayed on for some time. During these sojourns even the great capacity of the House must have been fully taxed, for royal state was kept up, as in the days of Elizabeth when, as we may gather from Paul Hentzner's Itinerary, it must have reached its climax. For instance, at Holdenby, the "say" was given, and the cup served on the knee, and all the state ceremonies of ancient days observed. It is further gathered from letters written to Rome from Northampton, by two Italian priests, who had visited Henrietta Maria at Holdenby, towards the end of 1636 , that she had in the House her own private chapel, of which the fittings and services caused much local comment. An interesting account is given of the pretty unconventional ways of the impulsive Catholic daughter of the illustrious Huguenot king, then in the heyday of her beauty and happiness at Holdenby, "Great Gloriana," the subject thirty-three years later of the impassioned Oration of Bossuet.

It was, therefore, to a well-known and favourite spot that the monarch was brought in 1647, arriving on February 15th, "in white weather." The omen was inauspicious. It will be remembered that exactly two years later " the White King" was borne obscurely to his grave at Windsor, devoid of the rites of the church to which he was so attached, under a black velvet pall that was blanched with snow.

The king, with the Parliamentary Commissioners, left Newcastle on the ominous date of January 30th, 1647, escorted by nine hundred horse and dragoons, who were subsequently quartered in the immediate neighbourhood. In a scarce tract, entitled "Gallant News for London from His Majesties Royal Court at Holmby," it is stated 
that "There were great tryumph at Northampton upon Tuesday last, when the tydings were brought that his Majesty were neere Holmby, the Bells rang, and the greet Guns went of, insomuch, that a gallant echo made its appeal at Holmby, and the sound thereof did much rejoice his Majesties Heart." On the king's arrival at Holdenby we are further informed that "there was a gallant guard appointed for his Majesty to passe by, who entred in at the great Court Gate, being accompanied by the Commissioners ${ }^{1}$ of both Kingdoms"; and that the king " entred the house in great tryumph, and in a most sumptuous maner."

The preparations made by the commissioners for the reception of the king were of the fullest kind. All the officers of the Household were in their places, the gentlemen of the Chamber, the pages, the grooms, the ushers, the waiters, the officials of the kitchen, cellar, buttery, pantry, pastry, spicery, confectionery, napery, and other departments, and the array of household servants-- but only one laundress-all were in their appointed order, and in the ample and beautiful house all were accommodated, as Sir Thomas Herbert says, "with all things needful." In addition, room was found for the commissioners, their chaplains, gentlemen, attendants, and others, and as the same author and eyewitness reports, "all within the King's House without straitning; and all the Tables were as well furnished as they used to be when his Majesty was in a peaceful and flourishing State."

In this great establishment the king, when he dined and supped, "always said Grace himself, standing under the State." This appears to have been a movable canopy. And " every Sunday the King sequestred himself to his private Devotion." His own chaplains were denied him, and he stiffly refused to assent to Presbyterianism and conform to the new directory; to attend the services in

1 They were Philip, Earl of Pembroke, Bazil, Earl of Denbigh, and Edward, Lord Montagu, on the part of the Lords; and Sir John Coke, Sir John Holland, Sir Walter Rarle, and Sir James Harrington, Baronets; John Crewe, Esq., and Major-General Browne, on the part of the Commons.
2 Gallant Neu's, etc., Memorials of Holdenby, ut sup., pt. ii, p. xxxiij.

3 Memoirs of the Last Two Years of the Reign of Kring Charles I., 15. (Edit. 1813.)

${ }^{4}$ Ibid., 16.

s Ibid., 17. 
the chapel, where the commissioners' chaplains officiated, or to permit them to say grace before him. And it is certain that the King would not have found the services in Holdenby church such as he could have approved of. He obtained no answer to his pathetic appeals to both Houses of Parliament for the presence of some of his chaplains whom he so "esteemed and reverenced," and the conscientious monarch thus bereft, in the hour of his need, of the consolation which for him meant so much, "sequestred himself to his private Devotion." Doubtless in some of those hours of "Solitudes and Sufferings" he pondered over the "Penitentiall Meditations and Vows at Holmbey," which find a place in the Eikon Basilike. It presents a sad and melancholy picture.

The assay of the viands, and the serving of the cup and of the covered dishes on the knee, was carried out with the ancient regal formality at Holdenby. But all the accustomed court state ceased when the king came to St. James's and his trial was determined on. The absence of these ceremonials were, as Herbert puts it, " an uncooth sight unto the King," who felt it deeply.

More particularly with regard to the king's manner of life, the same author tells us that he "would walk oft in the garden at Holmby with one or other of the Commissioners, and in regard there was no BowlingGreen then well kept at Holmby, the King rould sometimes ride to Harrowden, a House of the Lord Vaux's about nine miles off, where there was a good Bowling-Green, with Gardens, Groves, and Walks that afforded much pleasure. And other whiles to Althorpe, a fair House about two or three miles from Holmby, belonging to the Lord Spencer, now Earl of Sunderland, where also there was a Green well kept."3

King Charles showed himself gracious and affable to the people in Northamptonshire, who flocked to him to be touched for the Evil.

Herbert tells us further that " His Majesty, during his Stay at Holmby, such times as he did not ride abroad for Refreshment, would walk in the long Gravel-Walk in the Garden; where the Earl of Pembroke was ofttimes

\footnotetext{
1 Reprinted in Memorials of Holden$b y$, ut sup., p. Irxiij.

${ }^{2}$ Herbert, ut sup., 157 .

3 Herbert, ut sup., 18.
} 
with the King, and, not without some Difficulty, held pace with him, his Majesty being quick and lively in his Motion. And other times with others of the Commissioners, but most with Major-General Browne, with whom the King was pleased to discourse often. And whensoever the King thus recreated himself, he never had above one in Company, the rest keeping at a becoming Distance in some other part of the PrivyGarden."

The "Long" or "King's Walk" on which the troubled monarch paced rapidly backwards and forwards, crowns the succession of terraces. Nature, in her healing mood, has long since covered the gravel with the greensward. The straight platform, perhaps, after that at Windsor, the most historic walk in England, is three hundred and twenty yards long and eight yards wide. It has unfortunately been disregarded in modern days and broken into, where it crosses the plateau, in the laying out of the new gardens (Plate VIII).

The halting Lord Chamberlain was Philip, fourth Earl of Pembroke, one of the greatest noblemen of the kingdom, he who married that intrepid lady, Anne Clifford, whose name long sounded as a trumpet blast in wide districts of the north. ${ }^{2}$

Very little beyond what may be gathered from Thorpe's Plan can be determined with regard to the interior of the house. Norden only describes the Hall, in which he says: "There are raised three Peramides," very high, standing instead of a Shryne, the midst whereof ascendeth unto the Roofe of the Hawll, the other two equal with the syde Walls of the same Hawll; and on them are depainted the Armes of all the Gentlemen of the same Shire, and of all the Noblemen of this lande."4

Lord Burghley stayed one night at Holdenby on August 9th, 1579. Sir Christopher Hatton could not be there to receive him, because leave of absence was

I Herbert, ut sup., 23.

2 She was the only child of that striking character George Clifford, Earl of Cumberland, Champion of Queen Elizabeth. See Archaeological Journal, vol. Ivi, p. 187, Sept., 1899, paper on Samuel Daniel and Anne Clifford, by the writer.
3 Portions of these are preserred at Holdenby House.

4 Speculi Britanniae Pars altera; or a Delineation of Northamptonshire, by the Travayle of John Norden in the year MDCX, quoted in Memorials of Holdenby, ut sup., p. xxrij. 
not obtainable from his imperious mistress. The house, then hardly finished- " this goodly perfect, though not perfected, work," found great favour with the minister, who was particularly struck with the stately ascent "from the hall to the great chamber." This saloon must have been on the first floor, in the centre of the south front, immediately over the chapel, and forming part of the suite of state rooms known as the King's Lodgings, which continued westward along the façade. The Great Chamber appeared to Lord Burghley as so "answerable with largeness and lightsomeness, that truly a Momus could find no fault." "It was lighted by a triple window of remarkable character, running up through all the stories of the house, such a constructional effort as a modern architect would, perhaps, hardly be bold enough to project, even on paper, in these degenerate days! It must have been a magnificent room, and, apart from the consideration of the usual carved and moulded oak fittings, the flat or coved plaster ceilings rich with "knot" or strap work, and the "many costly and rare chimney pieces" of this regal suite, one thinks naturally, in connection with some of the rooms, of walls hung with brocades "of silk and silver," like Imogen's chamber ; of others covered with storied arras or tapestry from the looms of the Low Countries, and depicting now pagan mythology, now Biblical pieces; of embossed leather hangings from Cordova, brilliant with gold, silver, and colours. As to furniture, there must have been sideboards of degrees, after the mediaeval manner, displaying plenishings of plate, and "cupboards" of glasses facon de Venise, perhaps diamond-etched, after the king's own heart, by one of the beautiful and accomplished Dutch gentlewomen, Anna, Maria, or Gertrude Roemer Visscher. And, we may be sure, masterpieces of armour embossed and damascened by the Negrolis and Colmans. Imagination contemplates in the panelled royal rooms and closets at Holdenby " painted tables," "stained cloths," "large as ye life," or "done after ye quick," and many a " history piece" on the oak walls; inlaid Florentine cabinets; "purslane" from far Cathay; foot cloths from Persia, and ponderous native-made oak tables spread with

I Specialised in the Parliamentary Surrey of 1650. 
"Turkey work," such as Mytens and Van Somer loved to depict. Alongside of these refinements must have been chambers deeply panelled and inlaid with ebony, ivory, and walnut; canopied velvet and beplumed bedsteads; barbarous angular oak chairs covered with priceless damasks and fringed with silk or gold; comfortless joint stools, and hard oak benches. As to classic art in marble, we know from an inventory that the king had a number of busts at Holdenby, which were sold after his death. ${ }^{1}$ The more valuable objects had evidently been seized before.

Of the probable use of the rooms on the eastern portion of the south front, we have no knowledge, save that behind them, as we gather from Thorpe's plan, ran the gallery of $\mathrm{T}$ shape, 140 feet long and 22 feet wide, with bay windows looking into the first court, and at its east end. It returned half-way down, of the same width, advancing to two great windows in the south front. This must also have been a noble apartment, and Herbert tells us that the king used to walk in it for exercise. The Queen's Lodgings were on the north side of the house.

Like the hall, and the great chamber, the gallery was a constant feature in the large Renaissance houses. It was the common room where the family could assemble, and the children played their games; and here stood chests and trunks, hence the name of the "trunk gallery"; it served the same uses as the mediaeval cloisters in monastic establishments. For the purpose of comparison: there is a splendid gallery, forty years later in date than Holdenby, at Aston Hall, 140 feet long and 18 feet wide, with a rich plaster ceiling and beautiful panelled walls ; the gallery at Kirby is 150 feet long, and only 16 feet wide; and that at Haddon 110 feet long, and 17 feet wide, broken by three wide projecting bays.

Thus it was at least among sumptuous surroundings that the king in his lonely state, " every Sunday sequestred himself to his private Devotion, and all other days in the Week spent two or three hours in Reading, and

1 An Inventory of Goods belonging to Memorials of Holdenby, ut sup., the late King at Holmby House, p. xxviij. 
other pious Exercises," his favourite authors at Holdenby being Andrewes's Sermons, Hooker's Ecclesiastical Polity, Shakespeare, Herbert, and translations of Ariosto and Tasso.

From the moment of his arrival at Holdenby, Charles I. entered into negotiations with both Houses of Parliament. His first message concerned his desire to have the attendance of some of his chaplains, for the exercise of his conscience, and the assistance of his judgment regarding the present religious differences. This requisition and another on the same subject three weeks later, were taken no notice of. Six weeks after there seemed a prospect of "a safe and well-grounded peace" being arrived at. The king then agreed to certain important concessions, and desired a personal conference. In the midst of the vacillating deliberations of the parliament, as to the disposal of the king's person, he was suddenly snatched from them by the daring of Cornet Joyce and placed in the charge of the army.

It was on June 2nd that a party of seven hundred horse, selected from every regiment and "obscurely headed," arrived at Kingsthorpe, four miles from Holdenby; they rested on Harlestone Heath, and intelligence being brought to the commissioners, the gates were closed, the king's guard doubled, and preparations made for defence. During the night the troops advanced, and surrounded Holdenby House, and at daybreak their leader, Cornet Joyce drew up his forces at the back of the house. The king's troops fraternised with their old comrades, and opened the gates. Colonel Graves, the governor, fearing capture, on the advice of the commissioners, reluctantly fled. Joyce set the guard and posted the sentinels, assuring the commissioners at noon that their orders given to him would be carried out consistent with the king's safety. A period of tranquillity ensued, but understanding later that Graves had gone for succour, Joyce determined that the king should be removed without delay. At midnight he forced his way, pistol in hand, into the royal bedchamber, and announced his intention. To this the sovereign finally consented, provided that the assurances given by Joyce were confirmed by the soldiers under his command. 
On the following morning at six o'clock Joyce drew up his forces in the base court, facing the east window of the gallery. The king descended from his chamber, and addressed the party at some length, standing on the top of the steps of the grand entrance. ${ }^{1}$ He required to know under what commission Joyce was acting. "It is behind me," replied the Cornet, indicating the soldiers. "It is," said Charles, who had the pleasant courtesy, and, at times the happy tact of a Stuart, "in fair characters, and well written, legible without spelling." Finally, on the King's proposal, it was decided that he should be taken to Newmarket, and Lord Montagu, holding in his hand the written authority of parliament to the commissioners, for the care of the king, asked whether the soldiers sanctioned Joyce's proposition. They were unanimous. So there was no alternative, and on that day, June 4th, 1647, the four months of historic captivity came to an abrupt end. And Charles I. went from Holdenby House, stage by stage, and step by step to the scaffold, to which his political obliquity had fore-doomed him. But he possessed the true spirit of his race. "I fear not death," he said on the memorable occasion. "Death is not terrible to me, I bless my God I am prepared." Are not these things written with faithfulness and pathos in the pages of the Royalist Classic, the narrative of Sir Thomas Herbert, he who could not trust his heart "to endure the sight of that Violence they upon the Scaffold would offer the King," the shedding of the dark stream which floated Charles II. to the throne; the deed of a determined and avenging minority, and injurious to the cause of freedom.

From the chivalry at Whitehall to the doomed house at Holdenby is truly bathos. The Parliament decreed its downfall, and two years after the king's departure, under the evil auspices of a "roundhead" Yorkshire speculator, the evidences of Hatton's munificence and Thorpe's genius were soon dispersed over Northampton-

1 " The Perfect Narration betwixt his Majesty and Cornet George Joyce," written by Lord Montagu, was read in the House of Peers, June 10. 164.7. This statement shows that the king stood upon the top of the steps of the house, Joyce facing him at their foot. The exact spot where the memorable interview took place being thus known it seems desirable that a stone should be placed there recording the fact. 
shire. So had it been centuries before, when Hadrian's great barrier was treated as a stone quarry, and as at the sixteenth century upheaval, stately monastic buildings were scattered broadcast in countless districts.

In a Parliamentary Survey of Holdenby, made in 1650, preparatory to its sale and destruction, the following description of the garden is given :

"On the south syde of the saide Mansion House is a pleasant, spacious, and ffaire Garden, adorned with severall long Walkes, Mounts, Arbors, and seats, with curious delightfull Knotts, and in which Garden are many ffruite trees of divers kinds; on the south of the said Garden is a large Orchard, well planted, commonly called the Lower Orchard, sett artificially in Walkes with several Ascents, and in the said Orchard are Six ffish-ponds, well stored; on the west of the aforesaid Garden, lyeth another Orchard, comonly called the Upper Orchard, planted with several firute trees, and in it a long shady Walke; on the north syde of the said Orchard is a large Bowling Alley, and on the north and west of the said Bowling Alley, are two Walkes artificially set with well grown trees, and in the north west corner of the said Walks there is a pleasant Mountt; on the west syde of the aforesaid Garden and Upper Orchard, are two Spinneys, well set and grown with Ashes, and in them variety of delightful Walkes and on the east side of the said Spynneys, is a ffaire Water House, with a very large Cisterne, into which water is conveied by several leaden Pipis, from Sundry Heades, which serves the whole House and all the Offices thereunto belonging."

It may be noticed how much the compiler of a cold formal survey and appraisement, for sale and destruction, was carried away by the beauty of the place. $\mathrm{He}$ estimated the value of the house and offices as they stand, at $£ 6,000$, and the site of the house when cleared at twenty shillings a year. The Pleasant Mount particularised remains, and there is another east of the gardens, below the terraces.

The Survey mentions in the description of the House that there were "four magnificent towers or turrets" in the four corners of the first court. Such towers are faintly shown on Treswell's plan of the lay-out. Unless this drawing is merely a surveyor's conventional palace, one would say that Holdenby resembled Burghley in the general treatment of its outlines.

In the county town long remained three houses, of which the origin is unmistakable. They escaped the 

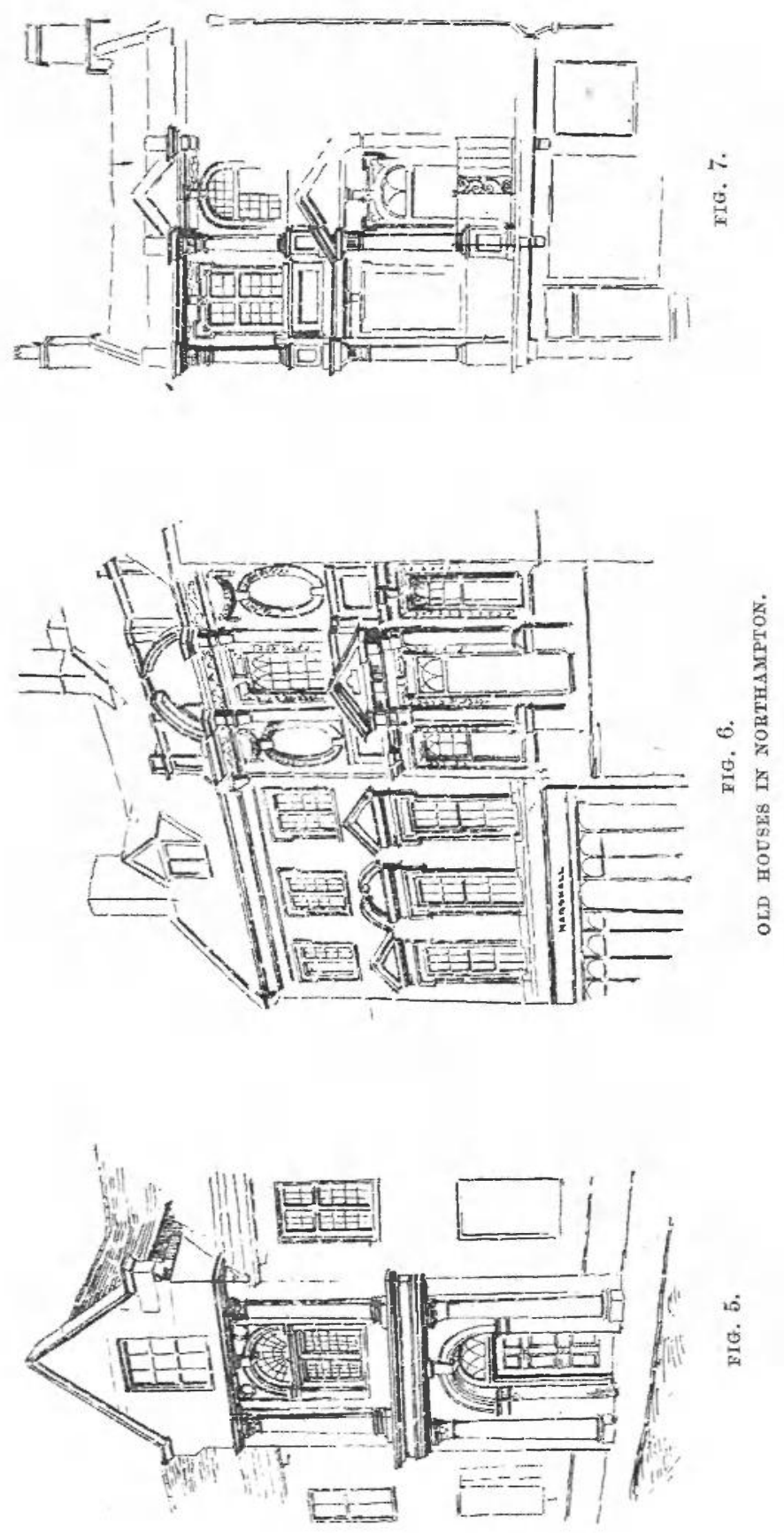
Great Fire of 1675 , but were removed some years ago. One of them was known as "Little Holmby." We have their accurate presentments in the late Mr. E. Pretty's drawings. ${ }^{1}$ Figs. 5, 6, 7. By taking the columniated portions shown, together with Thorpe's plan, and Stukely's sketch, by a process of reduplication, we can form an exact idea of the façades of Holdenby House, and from this material the principal parts of the great building could be reproduced on paper. There remains a house at the north-east corner of the Market Square, Northampton, of which some of the stone work may have come from Holdenby. It bears several coats of arms, and the expressive motto of the ancient princely family of Meyrick : HEB DDUW HEB DDIM DDUW A DIGON, "without God without everything, God and enough." In this manner Holdenby House, with its proverbial brightness, ${ }^{2}$ passed away, as Beranger might have put it :

Comme une etoile qui file,

Qui file, file, et disparait.

This essay may fitly end with the churchyard. Thanks to the refinement of the present possessors of the ancient Holdenby and Hatton estate here, the sacred acre is an ideally beautiful spot, secluded below Sir Christopher Hatton's plateau, "far from the madding crowd's ignoble strife," and appropriately surrounded by a wall formed, in the main, of sculptured Ketton stones from the House, set up by Mr. Amiand. Here are many memorials of the Clifden, Hartshorne, and Alderson families, which, together with the deathless historic aroma of the place, may, in the fullness of time, form further worthy objects of pilgrimage for wayfaring antiquaries, long after we have passed away.

1 These drawings form part of the bequest of the late Mr. M. H. Blosam to Rugby School and are here reproduced by the obliging courtesy of the Head Master.

2 The south front of Holdenby House contained a row of twenty-three great four-light mullioned and transomed windows, separated by Corinthian columns, the whole forming so great a display of glass surfaces as to have giren rise to the local proverb, still in use, "as bright as Holmby." We gather exactly what the glass at Holdenby was like from that still existing at Kirby Hall. It was cylinder-made, of a pale sea-green tint, and had many striations, "blebs," or bubbles in it, and the inequality of surface which added so much to the brilliancy of its appearance in the sun. See Oid English Glasses, 1897,212 , by the writer. 
PEDIGREE SHOWING THE ALLIANCE OF HATTON WITH HOLDENBY, AND THE SIX PRECEDING MARRIAGES OF HOLDENBYS, AS SHOWN BY THE AKHS ON THE FONT DESTROYBD IN THB "RestodatroN" OF 1867.

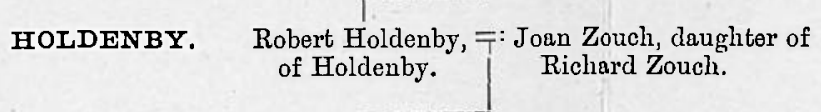

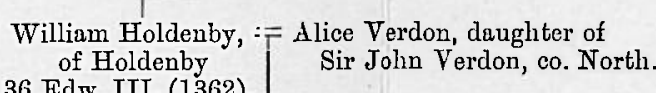

36 Bdw. III. (1362).

obert Holdenby, $=$ Maud de la Carrille, daughter

\begin{tabular}{c|l} 
of Holdenby, 16 Ric. II. \\
$\begin{array}{c}\text { (1395), ob. 4 June, 1411 } \\
\text { (12 Hen. IV.). }\end{array}$
\end{tabular}

1 (1)

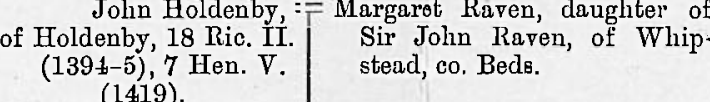

(141

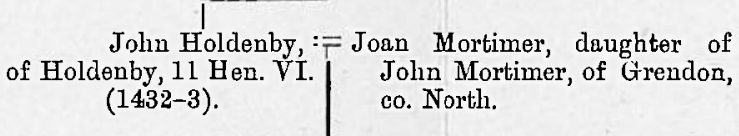

William Holdenby, : : : Alice Lucy, duughter of Sir

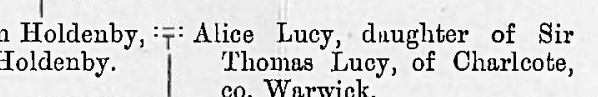

\section{HATTON.
Hatton of Quisty \\ (reshes, co. Cest.}

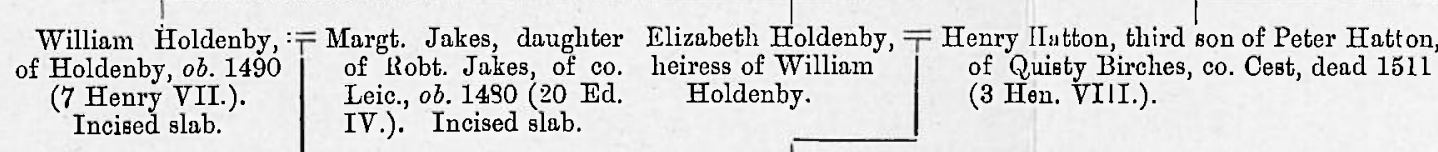

John Holdenby :: : : Joyce

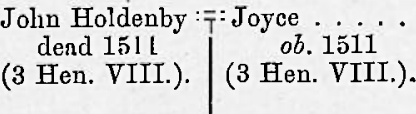

Robcrt Holdenby,
oh. v.p. and s.p.

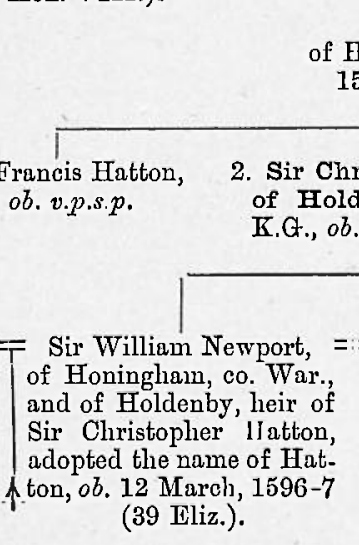

$\begin{gathered}\text { 1. William Hatton, } \\ \text { of Holdenby, ob. 29 Aug. } \\ 1546 \text { ( } 38 \text { Hen. VIII.). }\end{gathered} \mid \begin{gathered}\text { Alice Saunders, daughter } \\ \text { of Laurence Saunders, of } \\ \text { Harrington, co. North. }\end{gathered}$

John Hatton,
of Holdenby. Tane Westby, daughter of
John Westby, co. Kent.

ristopher Hatton,

John Newport, $=$ Dorothy Hatton, $\begin{array}{lll} & \end{array}$

(2)

., living 1579

2. Joln Hatton, $=$ Dionisia Ware, daughter co. Kent.

Su

thon,

June Shute, dunghter of

(1st wife.)

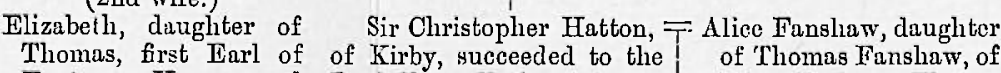
$\begin{array}{lll}\text { Exeter. Her second Lorl Chancellor's estates on } & \text { Of Thomas Fanshaw, of } \\ \text { Ware Park, co. Herts. }\end{array}$ daugliter all Gawdy, $=$ Tof Sir Francis Gawdy, and of Hollonby hir of

ord Chief Justich adopted the name of $\mathrm{Ha}$
ton, ob. 12 March, $1596-7$

husband was $\operatorname{Sir}$ Ed

ward Coke, , ord $\mathrm{O}$

Lorat Chancellor's estates on
death of Sir William (New-
port) Hatton. Sold Holdenby

Viscount Hatton,
extinct 1762 .

1

Thomas Hatton, $\bar{T}$ Mary, duuglite

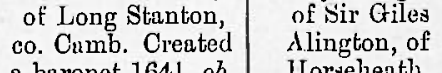

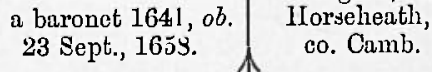

ob. 163is

\author{
N.B. - Anne, daughter of Christopher, Vi-count Hatton, married, a

